\title{
ASSESSMENT OF POLAND'S COMPETITIVE POSITION IN TRADE IN FUR SKINS AND THEIR PRODUCTS AGAINST A BACKGROUND OF THE EU COUNTRIES
}

\author{
SEBASTIAN KUBALA \\ CHRYSTIAN FIRLEJ
}

\begin{abstract}
The presented article attempts to assess the competitiveness of foreign trade in fur skins and their products in Poland against a background of the European Union countries between 2005 and 2016. The data used for the research came from the statistical yearbooks of the Central Statistical Office, and the study was supported by methods of descriptive and comparative analysis. It also used the data of the International Trade Center (ITC) and Faostat database. The results of the research confirmed that Poland has a competitive advantage in foreign trade in fur skins and their products in 2005 as well as in 2008-2011 and 2013-2016. In addition, Poland recorded one of the highest trade coverage ratios between 2010 and 2017 among the EU countries. It was found that, recently, Poland noted one of the fastest rates of competitive advantage in this respect, and the concentration of production in Poland may strengthen its role in the international arena, and has more and more impact on the economic situation of producers operating in the industry.
\end{abstract}

Keywords: competitiveness, foreign trade, fur animals.

Kody JEL: O13, O52, Q17.

\footnotetext{
Mgr Sebastian Kubala, Uniwersytet Ekonomiczny w Krakowie, Kolegium Ekonomii, Finansów i Prawa, Katedra Rozwoju Organizacji; 31-510 Kraków, ul. Rakowicka 27 (kubalas@uek.krakow.pl). ORCID iD: 0000-0003-4021-9173.

Mgr Chrystian Firlej, Uniwersytet Rolniczy w Krakowie, Wydział Rolniczo-Ekonomiczny, Zakład Ekonomiki i Finansów Przedsiębiorstw, Instytut Ekonomiki i Zarządzania Przedsiębiorstwami; 31-120 Kraków, Aleja Mickiewicza 21 (chrystianf@poczta.onet.pl). ORCID iD: 0000-0001-7724-5717.
} 


\section{Introduction}

The issue of competitiveness of foreign trade in fur skins and their products not only in Poland but also in many of the European Union countries is extremely difficult, due to the existence of many ethical controversies on breeding minks and other fur animals. On the one hand, we are dealing with the arguments presented by animal defenders, their postulates and campaigns, and on the other, it is necessary to take a rational attitude towards economic benefits of pursuing a widespread business consisting in breeding minks and other animals commonly known as fur animals. When perusing foreign and Polish internet portals devoted to this subject, we can grasp the arguments of both parties, but the priority task is to grasp their rationality. The study attempted to assess the competitiveness, so, as it is provided by the Encyclopedia of Management- conducting activities aimed at achieving the same or similar objectives, which at the same time and in the same environment are sought by other economic entities. Competitiveness can be defined as an ability to plan, create and sell a product more attractive than that of competitors (Encyklopedia Zarzadzania, 2019). In analysing the reference of this definition to the current situation in Poland and the European Union, it is necessary to take into account what main arguments are on the side of producers, and in the case of Poland - mainly exporters of fur skins and their products, what are their competitive advantages in relation to producers in other countries, while not necessarily addressing lobbying accents and attempts of other countries to take over our market.

Going to analytical studies, it should be noted that the way in which the various agricultural sectors operate and changes taking place in agriculture in the European Union are reasons for which considering the competitiveness of individual industries gives us valuable knowledge also enabling the development of possessed advantages in this area. The issue of competitiveness of foreign trade of Polish agriculture is the frequently raised subject, which was particularly evident at the time when our country joined the economic structures of the European Union. In Poland, the subject of competitiveness in general terms was addressed by e.g.: Urban (2003), Rytko (2008), Misala (2011), Nosecka, Pawlak and Poczta (2011), Juchniewicz (2014), Wieliczko (2014), Firlej (2017), Firlej and Kubala (2018). Analytical studies with regard to one of the most modern special sectors of agriculture: fur market, where farms are considered as sources of social and economic benefits in the development of the local economy were conducted by the authors such as: Firlej, Firlej and Kubala (2018), Dacko, Firlej, Łapiński, Niedziółka and Zawadka (2017), Jakubowski (2017).

\section{Objective of the studies}

The proposed main objective of the study was to assess the competitiveness of foreign trade in fur skins and their products in Poland against the background of the European Union in 2005-2016. The authors of the study fully agree with the argument of the Polish Association of Breeders and Producers of Fur Animals that the fur industry "gives employment to owners of fur animal farms and their fami- 
lies, hired workers, producers of farm equipment, producers of medicinal products, farmers producing cereals, owners of meat and fish processing plants and their workers, veterinarians (Fermowe zwierzęta, 2019).

The study conducted has been based on the international trade statistics of the individual European Union countries in the field of raw fur skins, tanned or finished fur skins and clothes, accessories and other fur skin articles. The reference base for calculating comparative advantages was the export value of agricultural products. The data source was the International Trade Centre (ITC) and the FAOSTAT database. The article uses abbreviations of country names according to the ISO 3166 standard (GUS, 2019).

\section{Methodology of studies}

The basic indicator that allows to assess the level of competitiveness in foreign trade is the Revealed Comparative Advantage Index (RCA) proposed by Balassa (1965). This index is calculated according to the formula:

$$
R C A_{i}=\frac{X_{i j}}{\sum_{i=1}^{n} X_{i j}}: \frac{X_{i w}}{\sum_{i=1}^{n} X_{i w}}
$$

where:

$X_{i j}-$ export of the $i^{\text {th }}$ product by a given country $j$,

$X_{i w}-$ export of the $i^{\text {th }}$ product by a group of countries $w$,

$n-$ number of types of products.

The main task of the RCA index is to determine the relative share of a product group in the given country's export in relation to the share of the same product group in the export of a comparative area (Szczepaniak, 2014). According to the interpretation, the values of the RCA index below 1 mean that a given country does not have comparative advantages in the reference market. In turn, the values above 1 indicate the existence of revealed comparative advantages in trade in the analysed commodity.

It should be noted that this index has drawbacks as it is unlimited from the top, which means that it can assume any maximum value. Therefore, in order to get rid of the interpretation difficulties, it is reasonable to modify this index in the following way (Dalum, Laursen and Villumsen, 1998; Salamaga, 2013):

$$
R C A_{k}^{(a)}=\frac{R C A^{a}-1}{R C A^{a}+1}
$$

where:

$R C A_{k}^{(a)}$ - revised revealed comparative advantage index,

$R C A$ - relative comparative advantage index (Balassa index),

$a \quad-$ any positive number (exponent). 
The values of the revised RCA index may be within the range of $[-1 ; 1]$. The positive values of the indices inform of the existence of a revealed comparative advantage in the export of a given product, the negative values mean no advantage. At the same time, the index indicates the strength of an existing advantage. The values closer to 1 indicate a stronger advantage, the closer they are to - 1 the greater is the absence of an advantage. It should be noted that the adopted value of parameter $a$ determines the rate of convergence of the $\mathrm{RCA}_{k}^{(a)}$ index with the limit values of the range $[-1 ; 1]$.

The second index to assess the competitiveness is the Trade Coverage index, which represents the degree of covering import with export. Its objective is to determine the extent to which expenses for the import of a given product are covered by revenues from the export of that product. It determines the export specialisation of a given country in the analysed sector. It is calculated using the formula:

$$
T C=\frac{E x}{I m}
$$

where:

$E x$ - export value,

Im - import value.

According to the adopted interpretation, the index above 1 means a relative advantage over competitors in the analysed area and attests to the export specialisation. The values below 1 indicate, firstly, the weak competitive position in the analysed area, as well as a deficit in international trade.

\section{Results of the studies}

Breeding of fur animals in the European Union is concentrated in the northern countries, especially in Denmark, Finland and the Netherlands. Poland is also one of the countries with the largest production of fur skins in the European Union (Table 1). However, in the so-called fur production chain Poland plays a minor role, since this production is characterised only by the production of raw material, which is then exported. As indicated by the report of the West Social and Economic Research Centre, the first link of fur production accounts for, on average, $12.5 \%$ of the value of the finished product (Ocena sytuacji.., 2018). In the coming years, the production structure is expected to change because of a ban, introduced in 2012, on breeding fur animals in the Netherlands which comes into effect as from 2024 (Czerwińska, 2019). In the medium and long term, an increase in the share of the Eastern European countries and China in the production structure of fur animals is predicted (PwC..., 2014). 
European Union countries with the largest number of fur animal farms

Table 1 and production volume in 2014

\begin{tabular}{cccccc}
\hline No. & Country & $\begin{array}{c}\text { Number of fur } \\
\text { animal farms }\end{array}$ & No. & Country & $\begin{array}{c}\text { Production volume } \\
\text { (in head) }\end{array}$ \\
\hline 1 & Denmark & 1,533 & 1 & Denmark & $17,921,000$ \\
2 & Poland & 1,144 & 2 & Poland & $7,945,000$ \\
3 & Finland & 914 & 3 & Netherlands & $5,500,000$ \\
4 & Hungary & 200 & 4 & Finland & $3,830,000$ \\
5 & Netherlands & 185 & 5 & Greece & $1,800,000$ \\
\hline
\end{tabular}

Source: own study based on: https://www.fureurope.eu/wp-content/uploads/ 2015/09/Fur_Europe_Annual_Report_September_2015_smallsize.pdf (access date: 10.06.2019).

Breeding of fur animals covers the whole of Poland and the dominant breeding species are minks and foxes. However, as shown in Figure 1, breeding in Poland is characterised by a large diversification in the location of the breeding farms. Most of them are located in the region of Wielkopolskie Voivodeship (in 2014, there were 152 establishments there). Other areas with a large concentration of breeding establishments cover the belt of the coastal voivodeships (Zachodniopomorskie and Pomorskie Voivodeships), the belt of the south-eastern voivodeships (Podkarpackie and Lubelskie Voivodeships) and the central area (Mazowieckie Voivodeship).

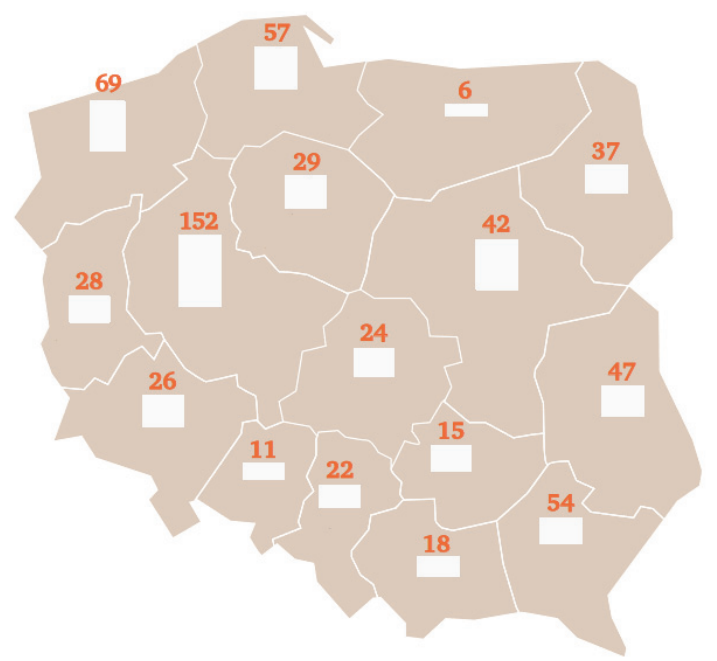

Fig. 1. Number of fur animal farms in Poland by voivodeships in 2014.

Source: own study based on the data of the General Veterinary Inspectorate. 
In the European Union, the largest share in the export of fur skins and their products in 2005 and 2016 was that of Denmark, its share between these years increased by $5.65 \%$ (Table 2). Other countries with significant shares include: Italy, Finland and Greece. Poland has recorded the largest increase in the share in the export of fur skins and their products in the European Union (to the level of $11.50 \%$ in 2016) between these years.

Table 2

European Union countries with the largest share in the export of fur skins and their products in 2005 and 2016

\begin{tabular}{cccccc}
\hline \multicolumn{2}{c}{2005} & & & \multicolumn{3}{c}{2016} \\
\hline No. & Country & Share (in \%) & No. & Country & Share (in \%) \\
\hline 1 & Denmark & 26.26 & 1 & Denmark & 31.91 \\
2 & Finland & 14.79 & 2 & Italy & 15.66 \\
3 & Italy & 12.72 & 3 & Finland & 11.90 \\
4 & Greece & 11.60 & 4 & Poland & 11.50 \\
8 & Poland & 4.27 & 5 & Greece & 7.07 \\
\hline
\end{tabular}

Source: own study based on the data of the International Trade Centre.

In 2005 and between 2008 and 2016 Poland achieved a positive trade balance in trade in fur skins and their products (Fig. 2). Over the years, the values between the export and import differed, on average, by USD 197,856.2 thousand. In 20062007, a negative trade balance was observed (in 2006 in the amount of USD 28,896 thousand, and in 2007 in the amount of USD 11,031 thousand). Between 2005 and 2016, there was an increase in the export of fur skins and their products by $192.45 \%$. In the first post-accession years, the main customers of the Polish commodities were the European Union countries. This situation began to change gradually since 2010, when as a result of opening the representation of the Canadian exchange (NAFTA) the export to the North American countries started to gain in importance. Currently, about $90 \%$ of the total export is sent only to three countries (International Trade Centre, 2019): Canada, Denmark and Finland (in 2016, the total export value to those countries was: $55.75 ; 17.54 ; 14.54 \%$ ). It should be noted, however, that these are the countries of sale, not of the final destination. Worldwide trade in fur skins and their products is conducted by specialised auction houses which operate mainly in Denmark, Finland, Canada and the USA (Bielański, Wrzecionowska, 2013). This attests to building a competitive position based on the quality of products offered. 


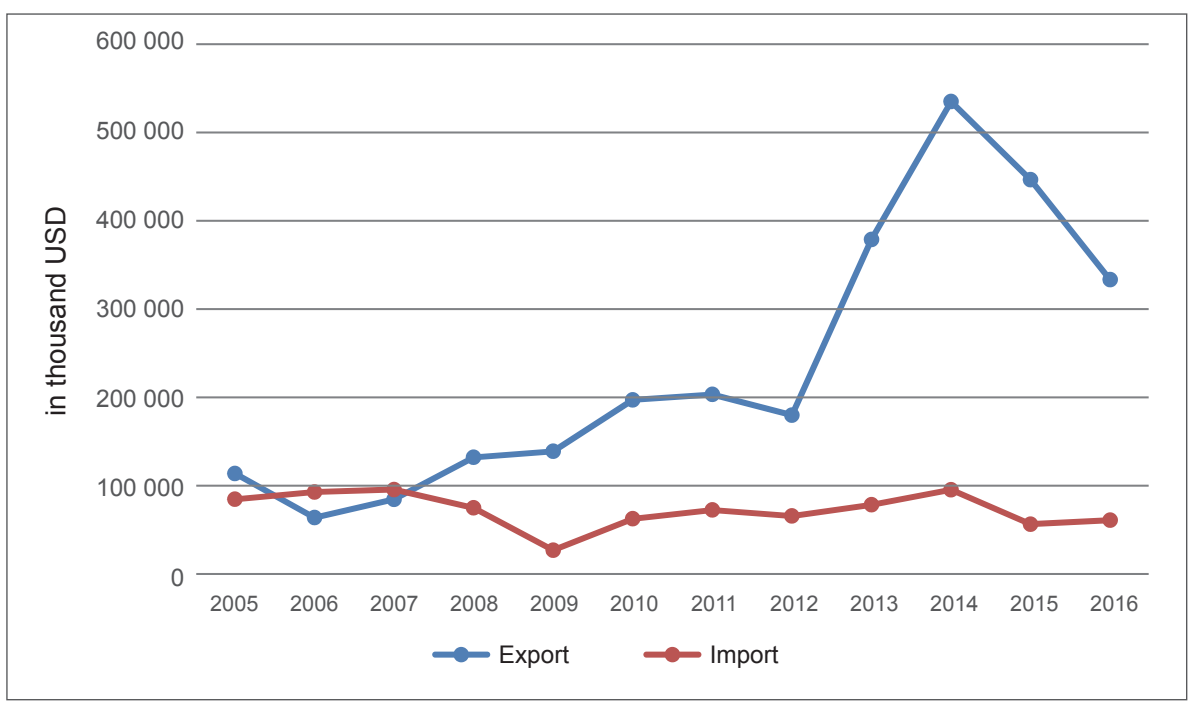

Fig. 2. Export and import values of fur skins and their products in Poland in 2005-2016. Source: own study based on the data of the International Trade Centre.

At the first stage, the RCA index has been calculated, as a quotient of a ratio of the export of fur skins and their products in a given country to the total export of fur skins and their products in the European Union countries and a ratio of the export of agri-food goods of this country to the total export of agri-food goods in the European Union countries. The revised relative comparative advantage index (Table 3) has been applied in the course of further analysis. The calculations adopted the value of parameter a at level 1 .

The level of the revised RCA index informs that in trade in fur skins and their products in Poland there was a competitive advantage in the years 2005, 2008-2011 and 2013-2016. The high competitive position of Poland in the European Union with regard to fur skins and their products results mainly from the high quality of skins produced in Poland. At the same time, it should be pointed out that prices of fur skins obtained by the Polish producers do not differ substantially from prices obtained by producers in other Member States. Only 6 European Union countries are characterised by positive values of the revised RCA index in all analysed years: Denmark, Estonia, Finland, Greece, Italy and Lithuania. The highest value in 2016 was achieved by: Finland, Denmark and Greece (the revised RCA index values are, respectively: $0.94 ; 0.82 ; 0.70)$. Poland in 2016 is characterised by the level of 0.39, which gives it the fifth place among all the European Union countries. For 17 countries, there is no comparative advantage in each analysed year. The lowest level of the index in 2016 was characteristic of Malta, Ireland, Romania, Luxembourg and Belgium. 
Table 3

Revealed comparative advantage (RCA) index of fur skins and their products in the European Union countries in 2005-2016

\begin{tabular}{|c|c|c|c|c|c|c|c|c|c|c|c|c|}
\hline Country & 2005 & 2006 & 2007 & 2008 & 2009 & 2010 & 2011 & 2012 & 2013 & 2014 & 2015 & 2016 \\
\hline AT & -0.66 & -0.67 & -0.6 & -0.72 & -0.77 & -0.82 & -0.79 & -0.76 & -0.78 & -0.74 & -0.8 & -0.72 \\
\hline $\mathrm{BE}$ & -0.81 & -0.82 & -0.81 & -0.85 & -0.78 & -0.79 & -0.79 & -0.81 & -0.86 & -0.84 & -0.89 & -0.9 \\
\hline BG & -0.35 & -0.46 & -0.58 & -0.91 & -0.97 & -0.96 & -0.94 & -0.97 & -0.92 & -0.94 & -0.95 & -0.78 \\
\hline CY & -0.84 & -0.74 & -0.85 & -0.94 & -0.99 & -0.99 & -0.9 & -0.95 & -0.76 & -0.47 & -0.54 & -0.51 \\
\hline $\mathrm{CZ}$ & -0.39 & -0.41 & -0.41 & -0.52 & -0.58 & -0.68 & -0.67 & -0.72 & -0.78 & -0.79 & -0.83 & -0.75 \\
\hline $\mathrm{DE}$ & -0.34 & -0.32 & -0.33 & -0.45 & -0.36 & -0.49 & -0.49 & -0.48 & -0.56 & -0.49 & -0.62 & -0.56 \\
\hline $\mathrm{DK}$ & 0.71 & 0.73 & 0.71 & 0.76 & 0.77 & 0.8 & 0.81 & 0.82 & 0.82 & 0.79 & 0.84 & 0.82 \\
\hline $\mathrm{EE}$ & 0.81 & 0.78 & 0.73 & 0.74 & 0.68 & 0.59 & 0.58 & 0.71 & 0.72 & 0.65 & 0.4 & 0.09 \\
\hline ES & -0.2 & -0.22 & -0.18 & -0.34 & -0.29 & -0.42 & -0.36 & -0.42 & -0.49 & -0.5 & -0.6 & -0.53 \\
\hline FI & 0.93 & 0.93 & 0.93 & 0.93 & 0.94 & 0.94 & 0.94 & 0.94 & 0.94 & 0.93 & 0.94 & 0.94 \\
\hline FR & -0.61 & -0.61 & -0.55 & -0.61 & -0.54 & -0.61 & -0.61 & -0.63 & -0.63 & -0.56 & -0.61 & -0.52 \\
\hline GB & -0.51 & -0.47 & -0.45 & -0.41 & -0.52 & -0.53 & -0.64 & -0.67 & -0.69 & -0.63 & -0.64 & -0.58 \\
\hline GR & 0.81 & 0.79 & 0.84 & 0.84 & 0.79 & 0.77 & 0.78 & 0.74 & 0.7 & 0.74 & 0.66 & 0.7 \\
\hline HR & 0.1 & -0.16 & -0.04 & -0.16 & -0.27 & -0.32 & -0.45 & -0.62 & -0.66 & -0.69 & -0.8 & -0.71 \\
\hline $\mathrm{HU}$ & -0.69 & -0.65 & -0.86 & -0.87 & -0.83 & -0.79 & -0.67 & -0.77 & -0.74 & -0.81 & -0.87 & -0.83 \\
\hline IE & -0.92 & -0.91 & -0.88 & -0.87 & -0.88 & -0.86 & -0.85 & -0.85 & -0.85 & -0.93 & -0.91 & -0.95 \\
\hline IT & 0.21 & 0.2 & 0.3 & 0.26 & 0.14 & 0.09 & 0.17 & 0.16 & 0.17 & 0.23 & 0.16 & 0.3 \\
\hline $\mathrm{LT}$ & 0.09 & 0.13 & 0.22 & 0.17 & 0.25 & 0.19 & 0.24 & 0.24 & 0.29 & 0.29 & 0.35 & 0.4 \\
\hline LU & -0.95 & -0.96 & -0.96 & -0.98 & -0.98 & -0.99 & -1 & -0.98 & -0.98 & -0.97 & -0.97 & -0.91 \\
\hline LV & 0.35 & 0.26 & 0.19 & 0.15 & 0.02 & -0.01 & -0.08 & -0.13 & -0.18 & -0.16 & 0.1 & 0 \\
\hline MT & -0.99 & -0.99 & -1 & -0.72 & -0.9 & -0.99 & -1 & -1 & -1 & -1 & -1 & -1 \\
\hline $\mathrm{NL}$ & -0.56 & -0.58 & -0.57 & -0.52 & -0.53 & -0.66 & -0.55 & -0.53 & -0.53 & -0.43 & -0.57 & -0.59 \\
\hline PL & 0.21 & -0.23 & -0.06 & 0.08 & 0.21 & 0.18 & 0.07 & -0.09 & 0.14 & 0.39 & 0.33 & 0.39 \\
\hline $\mathrm{PT}$ & -0.23 & -0.24 & -0.36 & -0.54 & -0.59 & -0.48 & -0.28 & -0.4 & -0.42 & -0.52 & -0.67 & -0.66 \\
\hline RO & -0.23 & -0.22 & -0.55 & -0.78 & -0.86 & -0.85 & -0.76 & -0.79 & -0.84 & -0.79 & -0.88 & -0.91 \\
\hline $\mathrm{SE}$ & 0.08 & 0.04 & 0.01 & -0.1 & 0 & -0.07 & -0.03 & -0.03 & -0.04 & -0.05 & -0.11 & -0.12 \\
\hline SI & -0.91 & -0.95 & -0.88 & -0.93 & -0.88 & -0.75 & -0.83 & -0.86 & -0.88 & -0.88 & -0.8 & -0.44 \\
\hline SV & -0.72 & -0.91 & -0.95 & -0.92 & -0.95 & -0.98 & -0.97 & -0.99 & -0.95 & -0.97 & -0.96 & -0.67 \\
\hline
\end{tabular}

Source: own study based on the data of the International Trade Centre and FAOSTAT. 
Considering the rate of changes in comparative advantages in the analysed group (Fig. 3), the upward trend is visible in 9 countries, the largest in the case of Lithuania (an increase in the value of the revised RCA index between 2005 and 2016 by $344.34 \%$ ), then in Poland, Slovenia and Italy (increase in the revised RCA index between 2005 and 2016, respectively, by $83.34 \% ; 51.77 \% ; 41.11 \%$ ). In the countries with the highest values of the revised RCA index (Denmark, Finland, Greece), small changes in its value are visible over the years (fluctuating between $-13 \%$ and $15 \%$ ). The countries such as Croatia, Romania and Sweden lost in importance to the largest extent.

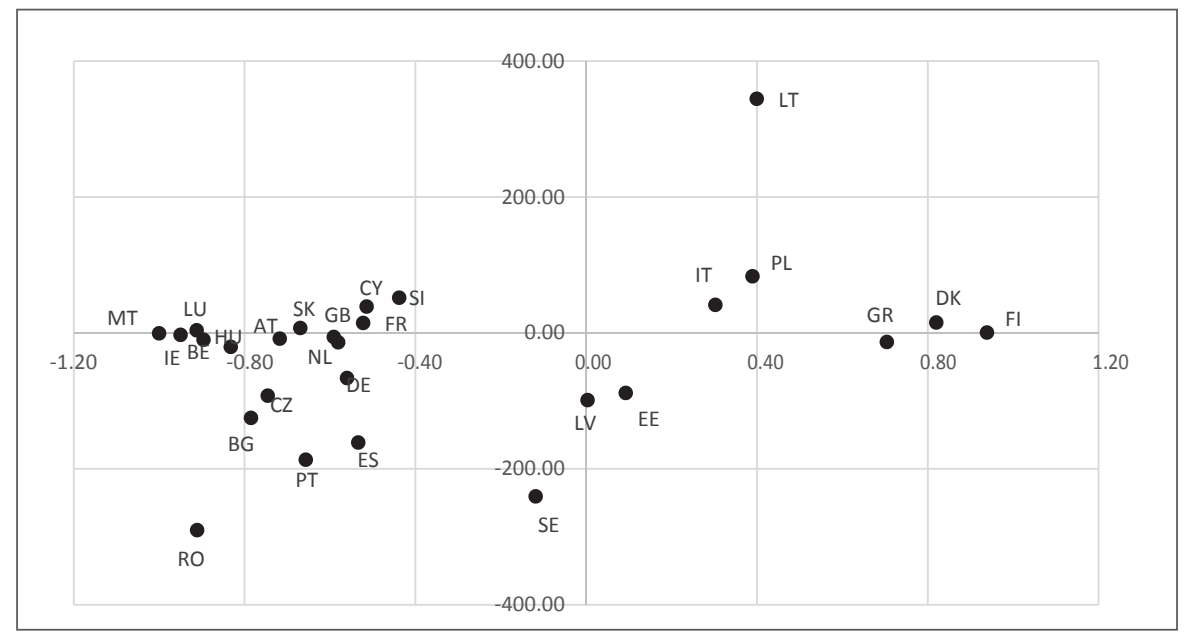

Fig. 3. Revised RCA indices in the Polish export of fur skins and their products in 2016 and changes when compared to 2005 .

Source: own study based on the data of the International Trade Centre and FAOSTAT.

The next stage of the studies covers an analysis of the Trade coverage index (Table 4).

The positive trade balance in the analysed product group was recorded in 12 countries. The largest level of the Trade Coverage index in trade in fur skins and their products in 2016 was recorded by Poland, then by Lithuania, the Netherlands and Latvia (the index values were, respectively, $5.45 ; 5.04 ; 3.58 ; 3.03$ ). In the case of Poland, in the last 4 years the values of the Trade Coverage index are among the largest in the European Union. The lowest level of the trade coverage index was recorded in 2016 in Malta, Romania and Luxembourg. Most of the countries where the values of the index are less than 1 are characterised by a partial or total ban on breeding fur animals (Austria, Slovenia, Slovakia, the United Kingdom), in some countries this was the result of the announcement of breeding bans in near future (Croatia, the Czech Republic, Luxembourg), and in the case of Belgium, Germany and Sweden this is a consequence of reducing the production volume (Free Fur Alliance, 2019; Raport na temat..., 2017). 
Table 4

Trade Coverage index of fur skins and their products in the European Union countries in 2005-2016

\begin{tabular}{|c|c|c|c|c|c|c|c|c|c|c|c|c|}
\hline $\mathrm{TC}$ & 2005 & 2006 & 2007 & 2008 & 2009 & 2010 & 2011 & 2012 & 2013 & 2014 & 2015 & 2016 \\
\hline AT & 0.63 & 0.67 & 0.66 & 0.51 & 0.37 & 0.38 & 0.46 & 0.52 & 0.53 & 0.52 & 0.39 & 0.41 \\
\hline $\mathrm{BE}$ & 0.99 & 1.05 & 0.89 & 1.07 & 1.01 & 1.19 & 1.01 & 1.07 & 1.26 & 0.96 & 0.9 & 0.84 \\
\hline $\mathrm{BG}$ & 2.49 & 1.7 & 0.62 & 0.23 & 0.11 & 0.16 & 0.26 & 0.19 & 0.52 & 0.33 & 0.65 & 0.84 \\
\hline CY & 0.15 & 0.33 & 0.09 & 0.03 & 0 & 0 & 0.04 & 0.01 & 0.09 & 0.14 & 0.22 & 0.36 \\
\hline $\mathrm{CZ}$ & 1.08 & 1.12 & 1.02 & 0.86 & 0.72 & 0.9 & 1.13 & 1.16 & 0.79 & 0.68 & 0.9 & 0.75 \\
\hline $\mathrm{DE}$ & 1.02 & 1.16 & 1.19 & 1.18 & 1.05 & 1.01 & 0.95 & 1.07 & 1.13 & 1.13 & 0.99 & 0.9 \\
\hline DK & 5.81 & 4.91 & 3.66 & 4.82 & 4.31 & 4.75 & 4.69 & 8.07 & 4.84 & 2.32 & 2.57 & 2.19 \\
\hline $\mathrm{EE}$ & 1.32 & 1.63 & 1.61 & 1.14 & 1.3 & 1.14 & 1.57 & 1.44 & 1.31 & 1.03 & 1.09 & 0.74 \\
\hline ES & 1.65 & 1.72 & 2.07 & 2.18 & 2.39 & 2.01 & 3.06 & 3.12 & 3.32 & 2.7 & 2.63 & 2.71 \\
\hline FI & 2.24 & 2.73 & 1.8 & 2.16 & 1.87 & 3.53 & 2.66 & 3.02 & 2.33 & 1.22 & 2.75 & 1.86 \\
\hline FR & 0.74 & 0.79 & 0.85 & 0.78 & 0.93 & 0.94 & 0.96 & 0.94 & 1.01 & 0.93 & 0.87 & 0.72 \\
\hline GB & 0.74 & 0.79 & 0.78 & 1.14 & 0.89 & 1.17 & 0.84 & 0.77 & 0.67 & 0.58 & 0.67 & 0.55 \\
\hline GR & 1.23 & 1.2 & 1.27 & 1.09 & 1.5 & 1.59 & 1.34 & 1.13 & 1.03 & 1.17 & 1.7 & 1.89 \\
\hline HR & 1.57 & 1.37 & 1.55 & 1.12 & 1.6 & 1.54 & 0.96 & 1.07 & 1.11 & 0.96 & 1.2 & 0.95 \\
\hline $\mathrm{HU}$ & 0.83 & 1.43 & 0.67 & 0.88 & 1.37 & 2.71 & 2.15 & 1.91 & 2.23 & 1.06 & 0.86 & 1.04 \\
\hline IE & 14.82 & 13.2 & 1.93 & 2.8 & 8.43 & 8.6 & 11.87 & 50.19 & 10.45 & 3.95 & 5.31 & 2.77 \\
\hline IT & 1.08 & 0.92 & 1.13 & 1.29 & 1.27 & 1.17 & 1.11 & 1.26 & 1.36 & 1.43 & 1.7 & 1.76 \\
\hline LT & 1.6 & 1.49 & 0.82 & 1.63 & 3.94 & 1.99 & 2.34 & 3.44 & 4.33 & 3.79 & 5.76 & 5.04 \\
\hline LU & 0.12 & 0.09 & 0.1 & 0.09 & 0.06 & 0.04 & 0.02 & 0.08 & 0.11 & 0.12 & 0.18 & 0.35 \\
\hline LV & 2.87 & 1.79 & 1.38 & 3.07 & 4.53 & 4.59 & 2.78 & 4.18 & 5.46 & 2.63 & 10.15 & 3.03 \\
\hline MT & -0.89 & -1.37 & -1.62 & 0.51 & -2.24 & -5.74 & -91 & -39.1 & -23.6 & -9.66 & -80.7 & -186.1 \\
\hline NL & 3.56 & 4.27 & 3.64 & 4.7 & 5.72 & 4.2 & 5.1 & 5.31 & 4.58 & 3.23 & 3.01 & 3.7 \\
\hline PL & 1.34 & 0.69 & 0.88 & 1.76 & 5.13 & 3.14 & 2.8 & 2.73 & 4.82 & 5.6 & 7.9 & 5.46 \\
\hline PT & 1.19 & 1.32 & 1.1 & 0.97 & 0.84 & 1.12 & 1.44 & 1.89 & 1.9 & 1.09 & 0.95 & 0.69 \\
\hline RO & 0.5 & 0.52 & 0.22 & 0.21 & 0.18 & 0.28 & 0.31 & 0.31 & 0.39 & 0.47 & 0.38 & 0.18 \\
\hline SE & 2.26 & 2.41 & 1.95 & 1.56 & 1.55 & 1.59 & 1.67 & 1.73 & 2.54 & 1.61 & 1.32 & 0.98 \\
\hline SI & 0.01 & -0.19 & -0.11 & -0.22 & -0.16 & 0.3 & 0.12 & 0.31 & 0.17 & 0.09 & 0.55 & 0.66 \\
\hline SV & 1.04 & 0.37 & 0.26 & 0.74 & 0.19 & 0.1 & 0.23 & 0.11 & 0.75 & 0.25 & 0.33 & 0.99 \\
\hline
\end{tabular}

Source: own study based on the data of the International Trade Centre. 
When observing the changes in the value of the Trade Coverage index between 2005 and 2016 (Fig. 4), it can be concluded that for 11 countries there was an increase in the value of the index. The largest increase in the export specialisation in fur skins and their products took place in the case of Slovenia, Poland and Lithuania (increasing the value of the Trade Coverage index between 2005 and 2016 by, respectively, $672.42 \% ; 306.00 \% ; 214.33 \%$ ). The countries such as Ireland and Bulgaria lost in importance to the largest extent.

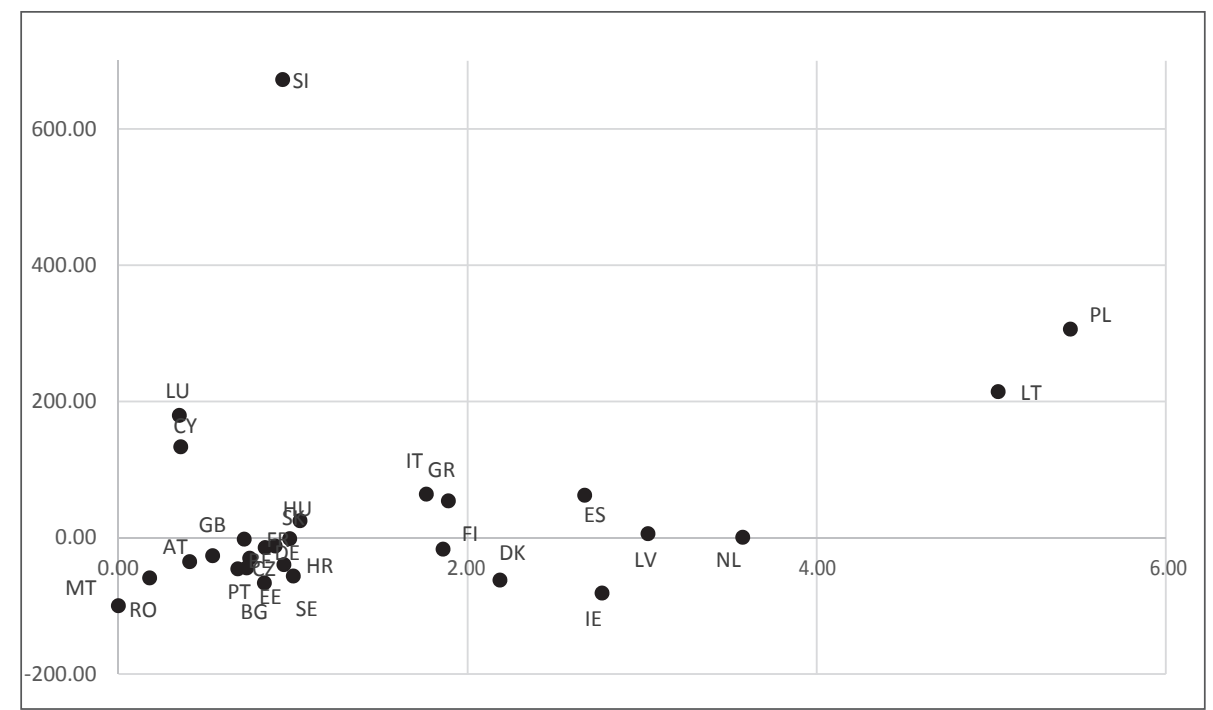

Fig. 4. Trade Coverage indices in foreign trade in fur skins and their products in 2016 and changes when compared to 2005 .

Source: own study based on the data of the International Trade Centre.

\section{Final conclusions}

The studies conducted made it possible to look objectively at the competitiveness of foreign trade in fur skins and their products in Poland against a background of other European Union countries in the years 2005-2016, in which such activities were carried out on a broader scale. The authors tried to highlight the value of the results obtained in terms of continuing breeding fur animals in Poland, while ignoring lobbying aspects and other actions affecting the implementation of particular interests of other countries, including, the hypothetical takeover of modern breeding in our country.

Based on the results of the studies, the following conclusions have been identified: 1. Taking into account the criterion of the location of fur farms, it was found that breeding fur animals in the European Union is concentrated in the Northern European countries, mainly in Denmark, Finland, the Netherlands and Poland. 
2. In Poland, contrary to the other European Union countries with the highest level of production, the production is based on producing raw material for export;

3. Poland had a competitive advantage in foreign trade in fur skins and their products in 2005, in 2008-2011 and in 2013-2016. It is one of the countries where the fastest growth rate of the competitive advantage between 2005 and 2016 has been recorded.

4. Poland is a country in which some of the largest Trade Coverage indices among the European Union countries were recorded in 2010-2017. Therefore, increasing the production of fur skins is an opportunity to develop the fur industry in Poland.

5. Taking into account the aspects of competitiveness of foreign trade in fur skins and their products in Poland compared with the European Union countries, it has been concluded that, in connection with the emerging restrictions on breeding fur animals in these countries, the concentration of production in Poland can strengthen its role on the international arena, as well as have an increasing impact on the economic situation of producers operating in the industry. 


\section{References}

Balassa, B. (1965). Trade Liberalisation and 'Revealed' Comparative Advantage. Manchester School of Economics and Social Studies, No. 33, pp. 99-123. DOI: 10.1111/j.1467-9957.1965.tb00050.x.

Bielański, P., Wrzecionowska, M. (2013). Organizacja obrotu skórami zwierząt futerkowych. Wiadomości Zootechniczne, r. LI, 1, pp. 93-100.

Czerwińska, A. (2019). Holandia podtrzymuje całkowity zakaz hodowli zwierzat na futra!. Retrieved from: https:/www.otwarteklatki.pl/holandia-podtrzymuje-calkowity-zakaz-hodowli-zwierzat-futra/ (access date: 09.06.2019).

Dacko, M., Firlej, K., Łapiński, S., Niedziółka, A., Zawadka, J. (2017). Wpływ hodowli zwierząt futerkowych na gospodarkę lokalna w Polsce. Raport Uniwersytetu Rolniczego im. Hugona Kołłątaja w Krakowie.

Dalum, B., Laursen, K., Villumsen, G. (1998). Structural change in OECD export specialisation patterns: de-specialisation and „stickiness”. International Review of Applied Economics, Taylor and Francis Journals, No. 12(3), pp. 423-443. DOI: 10.1080/02692179800000017.

Encyklopedia Zarzadzania. Konkurencyjność. Retrieved from: https://mfiles.pl/pl/index.php/ Konkurencyjno\%C5\%9B\%C4\%87, (access date: 16.06.2019).

Faostat (2019). Retrieved from: http://www.fao.org/faostat/en/\#home (access date: 09.06.2019).

Fermowe zwierzęta futerkowe. Polski Związek Hodowców i Producentów Zwierząt Futerkowych. Retrieved from: http://pzhipzf.pl/o-nas.html (access date: 16.06.2019).

Firlej, Ch., Firlej, K., Kubala, S. (2018). The Influence of Fur Farming on the Local Economy in Poland. Hradec Economic Days: Double-blind Peer Reviewed Proceedings of the International Scientific Conference Hradec Economic Days. Hradec Králové. Vol. 8(1), pp. 224-232.

Firlej, K. (2017). Przemyst spożywczy w Polsce. Nowa ścieżka rozwoju. Warszawa: Wydawnictwo Naukowe PWN.

Firlej, K., Kubala, S. (2018). The Assessment of Export Potential of Agricultural and Food Products in the Visegrad Group Countries in the Years 2005-2017. Economic Sciences for Agribusiness and Rural Economy: Proceedings of the 2018 International Scientific Conference, Warsaw. No. 2, pp. 167-173. DOI: 10.22630/ESARE.2018.2.21.

Fur Europe (2017). Retrieved from: https://www.fureurope.eu/wp-content/uploads/ 2015/09/ Fur_Europe_Annual_Report_September_2015_smallsize.pdf (access date: 10.06.2019).

Fur Free Alliance (2019). Retrieved from: htps://www.furfreealliance.com/fur-bans/ (access date: 09.06.2019).

Główny Inspektorat Weterynarii (2019). Retrieved from: https://www.wetgiw.gov.pl/ (access date: 10.06.2019).

Główny Urząd Statystyczny (2019). Retrieved from: https://stat.gov.pl/sprawozdawczosc/intrastat/ wykaz-panstw-czlonkowskich-unii-europejskiej/ (access date: 10.06.2019).

International Trade Centre (2019). Retrieved from: http://www.intracen.org/itc/market-info-tools/statistics-import-product-country/ (access date: 09.06.2019 r.).

Jakubowski, T. (2017). Dział specjalny produkcji rolnej „Hodowla i chów zwierząt futerkowych". Miejsce w polskim rolnictwie. Polski Związek Hodowców i Producentów Zwierząt Futerkowych.

Juchniewicz, M. (2014). Tendencje zmian międzynarodowej konkurencyjności przemysłu spożywczego państw Unii Europejskiej. Roczniki Naukowe Ekonomii Rolnictwa i Rozwoju Obszarów Wiejskich, No. 101(1), pp. 31-40.

Misala, J. (2011). Międzynarodowa konkurencyjność gospodarki narodowej. Warszawa: PWE. 
Nosecka, B., Pawlak, K., Poczta, W. (2011). Wybrane aspekty konkurencyjności rolnictwa. Konkurencyjność Polskiej Gospodarki w warunkach globalizacji i integracji europejskiej. Program Wieloletni 2011-2014, No. 7. Warszawa: IERGiŻ-PIB.

Ocena sytuacji branży hodowli zwierząt futerkowych i jej wpływu na gospodarkę polska (2018). Zachodni Ośrodek Badań Społecznych i Ekonomicznych, Gorzów Wielkopolski.

PwC (2014). Wpływ ekonomiczny branży hodowli zwierzat futerkowych na gospodarkę Polski. PwC Polska Sp. z o.o.

Raport na temat przemysłu futrzarskiego w Polsce (2017). Warszawa: Fundacja Międzynarodowy Ruch na Rzecz Zwierząt - Viva!.

Rytko, A. (2008). Zmiany konkurencyjności polskich produktów żywnościowych w latach 2000-2007. Zeszyty Naukowe SGGW w Warszawie. Problemy Rolnictwa Światowego, No. 5(20), pp. 153-161.

Salamaga, M. (2013). Badanie konkurencyjności polskiego eksportu z wykorzystaniem skorygowanego wskaźnika przewagi komparatywnej. Zeszyty Naukowe Uniwersytetu Ekonomicznego w Krakowie, No. 904, pp. 37-51.

Szczepaniak, I. (2014). Monitoring i ocena konkurencyjności polskich producentów żywności (5). Synteza. Program Wieloletni 2011-2014, No. 115. Warszawa: IERiGŻ-PIB.

Urban, R. (2003). Analiza przewag komparatywnych na poziomie przemystu rolno-spożywczego. Warszawa: IERiGŻ.

Wieliczko, B. (2014). Konkurencyjność sektora rolno-spożywczego UE w świetle wyników handlu zagranicznego wybranych państw. Zeszyty Naukowe SGGW w Warszawie. Problemy Rolnictwa Światowego, No. 14(29), pp. 226-237. 


\title{
OCENA POZYCJI KONKURENCYJNEJ POLSKI W HANDLU SKÓRAMI FUTERKOWYMI I WYROBAMI Z NICH NA TLE KRAJÓW UE
}

\begin{abstract}
Abstrakt
W przedstawionym artykule podjęto próbę oceny konkurencyjności handlu zagranicznego skórami futerkowymi i wyrobami z nich w Polsce na tle krajów Unii Europejskiej w latach 2005-2016. Dane liczbowe stużace do badań pochodziły z roczników statystycznych Głównego Urzędu Statystycznego, a w opracowaniu wsparto się metodami analizy opisowej i porównawczej. Wykorzystano także dane Międzynarodowego Centrum Handlu (ITC) oraz bazę Faostat. Wyniki badań potwierdzity, że Polska miała przewage konkurencyjna w handlu zagranicznym skórami futerkowymi $i$ wyrobami z nich $w$ roku 2005 oraz $w$ latach 2008-2011 i 2013-2016. Ponadto Polska jest krajem, w którym na przestrzeni lat 2009-2016 odnotowywano jedne z największych wskaźników pokrycia importu eksportem pośród krajów Unii Europejskiej. Stwierdzono, że Polska jest jednym z krajów, w którym odnotowano najszybsze tempo wzrostu przewagi konkurencyjnej w tym zakresie, a koncentracja produkcji w Polsce może umocnić jej rolę na arenie międzynarodowej, a także mieć coraz większy wpływ na sytuację ekonomiczna producentów działajacych $w$ omawianej branży.
\end{abstract}

Słowa kluczowe: konkurencyjność, handel zagraniczny, zwierzęta futerkowe.

Accepted for print: 11.12.2019.

O ile nie jest to stwierdzone inaczej, wszystkie materiały na stronie są dostępne na licencji Creative Commons Uznanie Autorstwa 4.0 Międzynarodowe.

Pewne prawa zastrzeżone na rzecz Instytutu Ekonomiki Rolnictwa i Gospodarki Żywnościowej - PIB.

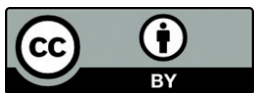

